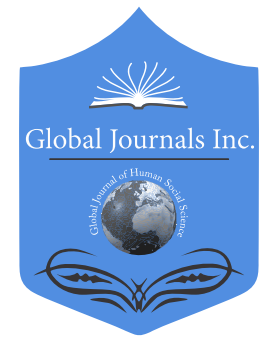

GLOBAL JOURNAL OF HUMAN-SOCIAL SCIENCE: B

GeOGRAPHY, GeO-SCIENCES, ENVIRONMENTAL SCIENCE \& DisASTER MANAGEMENT

Volume 21 Issue 2 Version 1.0 Year 2021

Type: Double Blind Peer Reviewed International Research Journal

Publisher: Global Journals

Online ISSN: 2249-460X \& Print ISSN: 0975-587X

\title{
Land Cover and Coastline Change Assessment of Nijhum Dwip, Bangladesh, using Geospatial Analysis
}

By Mohoua Sobnam \& Al Mamun

Begum Rokeya University

Abstract- Nijhum Dwip is a southern island of Bangladesh isolated from the mainland, in the convergence of the Meghna River and the Bay of Bengal. This island has studied through overlay analysis and supervised classification by geospatial and remote sensing technique, over 38 years (1980-2018) using multitemporal Landsat MSS, TM, OLI, and TIRS satellite images with identification of historical changes. This landform is facing frequent shifting of its coastline and leading to sequential changes on the land surface. Analysis revealed substantial growth of settlement and agricultural land whereas significant lessening on vegetation cover and open space. In 1990 agricultural land was $4.47 \mathrm{~km} 2$ (13.29\%) and improved to $9.16 \mathrm{~km} 2(19.17 \%)$ in 2018. Similarly, settlement also increased from $1.92 \mathrm{~km} 2(4.79 \%)$ in 1999 to $5.72 \mathrm{~km} 2$ (11.97\%) in 2018. Conversely, vegetation was primarily $8.02 \mathrm{~km} 2(27.71 \%), 18.70 \mathrm{~km} 2$ (55.61\%), 20.97 km2 (52.29\%), 18.47 km2 (36.28\%) and 15.28 km2 (31.98\%) in 1980,1990,1999, 2010 and 2018, indicating declination. As well, water bodies and open space also fluctuated through the period because of geomorphological processes and human intervention. Besides, the least and highest unstable char land was $1.15 \mathrm{~km} 2$ (3.42\%) and $1.68 \mathrm{~km} 2$ (5.80\%) in 1990 and 1980.

Keywords: dynamic, spatial analysis, land utilization, erosion-accretion processes, enlargement.

GJHSS-B Classification: FOR Code: 040699

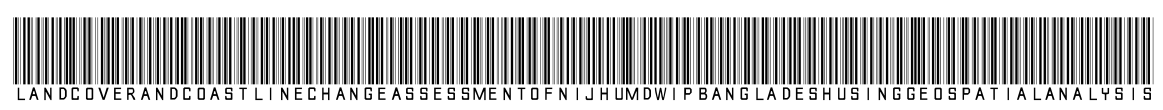

Strictly as per the compliance and regulations of:

(c) 2021. Mohoua Sobnam \& Al Mamun. This is a research/review paper, distributed under the terms of the Creative Commons Attribution-Noncommercial 3.0 Unported License http://creativecommons.org/licenses/by-nc/3.0/), permitting all non-commercial use, distribution, and reproduction in any medium, provided the original work is properly cited. 


\title{
Land Cover and Coastline Change Assessment of Nijhum Dwip, Bangladesh, using Geospatial Analysis
}

\author{
Mohoua Sobnam ${ }^{\alpha} \&$ Al Mamun ${ }^{\sigma}$
}

Abstract- Nijhum Dwip is a southern island of Bangladesh isolated from the mainland, in the convergence of the Meghna River and the Bay of Bengal. This island has studied through overlay analysis and supervised classification by geospatial and remote sensing technique, over 38 years (1980-2018) using multitemporal Landsat MSS, TM, OLI, and TIRS satellite images with identification of historical changes. This landform is facing frequent shifting of its coastline and leading to sequential changes on the land surface. Analysis revealed substantial growth of settlement and agricultural land whereas significant lessening on vegetation cover and open space. In 1990 agricultural land was $4.47 \mathrm{~km} 2$ (13.29\%) and improved to $9.16 \mathrm{~km} 2(19.17 \%)$ in 2018. Similarly, settlement also increased from $1.92 \mathrm{~km} 2(4.79 \%)$ in 1999 to $5.72 \mathrm{~km} 2$ (11.97\%) in 2018. Conversely, vegetation was primarily 8.02 km2 (27.71\%), 18.70 km2 (55.61\%), 20.97 km2 (52.29\%), $18.47 \mathrm{~km} 2$ (36.28\%) and $15.28 \mathrm{~km} 2$ (31.98\%) in $1980,1990,1999,2010$ and 2018, indicating declination. As well, water bodies and open space also fluctuated through the period because of geomorphological processes and human intervention. Besides, the least and highest unstable char land was $1.15 \mathrm{~km} 2$ (3.42\%) and $1.68 \mathrm{~km} 2$ (5.80\%) in 1990 and 1980. All over the study period, the island gained $18.84 \mathrm{~km} 2$ instead of $2.63 \mathrm{~km} 2$ loss, which indicates accretion is prominent than erosion. Findings from 1980 to 2018 indicating $2.125 \mathrm{~km} 2 / \mathrm{y}$ total average annual growth rate while enlargement rate was $0.469 \mathrm{~km} 2 /$ year (1980-1990), 0.719 km2/y (1990-1999), 0.937 km2/y (1999-2010) and 0.328 km2/y reduced in 2010-2018 as well. The upper portion of Nijhum Dwip is shifting more towards the north, east, and north-west direction than south. In 1990 and 1999, the coastline extended westwards while in 2010 and 2018 shifted to the northwest. Because of the dynamic nature of the coastal environment, this island experienced enlargement during the last 38 years.

Keywords: dynamic, spatial analysis, land utilization, erosion-accretion processes, enlargement.

\section{InTRODUCTION}

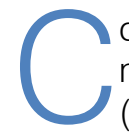
oastline and coastal areas of Bangladesh are neither uniform nor static, but also dynamic (Brammer, 2014) due to shifting through the short and long-term processes (Schwartz, 2006). The Coastal zone covers $32 \%$ of Bangladesh involving Jessore, Narail, Gopalganj, Shariatpur, Chandpur, Satkhira, Khulna, Bagerhat, Pirozpur, Jhalakati, Barguna, Barisal, Patuakhali, Bhola, Lakshmipur, Noakhali, Feni, Chittagong, and Cox's Bazar. Estuaries, islands, accreted land, beaches, peninsula, rural

Author a $\sigma$ : Department of Geography and Environmental Science, Begum Rokeya University, Rangpur, Bangladesh.

e-mails: mohouasobnam@gmail.com,mamunbrur95@gmail.com settlements, urban and industrial areas, ports, etc. are usual features (Iftekhar, 2006). Around 35 million people representing $29 \%$ of the total inhabitants live in the coastal zone (Uddin \& Kaudstaal, 2003). Except for Chittagong-Cox's Bazar, all parts of the coastal zone are plain land with extensive river networks and accreted land (Sarwar, 2005). The morphology of the coastal region in Bangladesh is quite unstable due to simultaneous erosion and accretion, variation of river flow, sediment load (Shibly and Takewaka, 2012). Besides, strong tidal currents, vigorous wave action (Sarwar \& Woodroffe, 2013) along the coast and physical environments, human interventions (Hassan et al., 2017) are other crucial reasons for the changes. Identically, mangrove forest is decreasing while cultivable lands and settlement are growing over the year (Hossain et al., 2016). However, rapid geomorphological changes are going on in the Meghna estuary (Brammer, 2014), also Nijhum Dwip is one of the islands in the Meghna estuary of the Bay of Bengal where changes are instantaneous. Along with, land use patterns are changing to meet the demand of society, which may be a concerning issue in the perspective of putting pressure on the environment and deteriorating newly formed land. Usually, land use changes indicating the land utilization by people (Anderson et al., 1976; Di Gregorio and Jansen, 1997; Lillesand and Kiefer, 2002) when change detection is practicing to identify the spatial changes of the surface of the earth at diverse temporal ranges (Singh, 1989). Various studies have carried out on islands with remote sensing and GIS techniques for detecting Spatio-temporal changes of the forest, erosion-accretion, and land use (Alam and Uddin, 2013; Sarwar and Woodroffe, 2013; Emran et al., 2016; Hossain et al., 2016; Kumara and Ghosh, 2012; Rahman et al., 2017; Rahman et al., 2018). Instead of this, very few studies noted here considered population migration, risk, vulnerability, and livelihood issues (Hossain et al., 2013; Islam et al., 2015; Kumar and Luna, 2018; Tanim et al., 2013). As study concerning Spatio-temporal changes on land cover and coastline of the Nijhum Dwip is less frequent, the present investigation is broadly an attempt to detect the land cover changes and evaluate the lateral shifting of coastline from 1980 to 2018 of Nijhum Dwip, Bangladesh. Therefore, coastal change detection is critical in coastal zone application and is significant for future coastal dynamic studies (Lu et.al. 2004). This research provides an integrated spatial analysis using 
time-series satellite images towards better management of the study area.

\section{Study Area}

For this study Nijhum Dwip (Silent Island) has selected as the study area, a mauza under Zahajmara Union of Hatiya Upazila of Noakhali district (PDO-ICZM, 2002) in Bangladesh. It is an extreme southern isolated small island of Bangladesh separated by the Hatiya channel (Alam and Uddin, 2013), about 2.2 meters high from the sea level situated in the Meghna estuary, confluences of the Bay of Bengal and enclosed by the Bay of Bengal (South and West), Domar char and the Meghna River on the East and Hatiya Island on the North (Saha et al. 2014). Nijhum Dwip lies between $22^{\circ} 1^{\prime} 30^{\prime \prime} N$ to $22^{\circ} 6^{\prime} \mathrm{N}$ latitudes and $90^{\circ} 58^{\prime} 30^{\prime \prime} \mathrm{E}$ to $91^{\circ} 3^{\prime} \mathrm{E}$ longitudes (Figure 1). During 1960 this island was a small piece of sandy barren land and in 1970 devastating cyclone swept away almost all. This island is divided into two parts by a canal, named Kamalarpur (Northern part) and Char Osman (Southern Part) that is mostly populated. This mudflat land is still unstable because of erosion, deposition, storm surge, monsoon inundation, cyclone, etc. for safe living rather than supporting people's livelihood as located in the west of Char Damar, east of Manpura, south of the Hatia Mainland, and north of Bay of Bengal. Instead of these risks, the population is increasing from 4372 to 7835 and then 12796 in 1991, 2001 to 2011, along with the total number of households are 2464 (PDO-ICZM, 2002; BBS 2011).

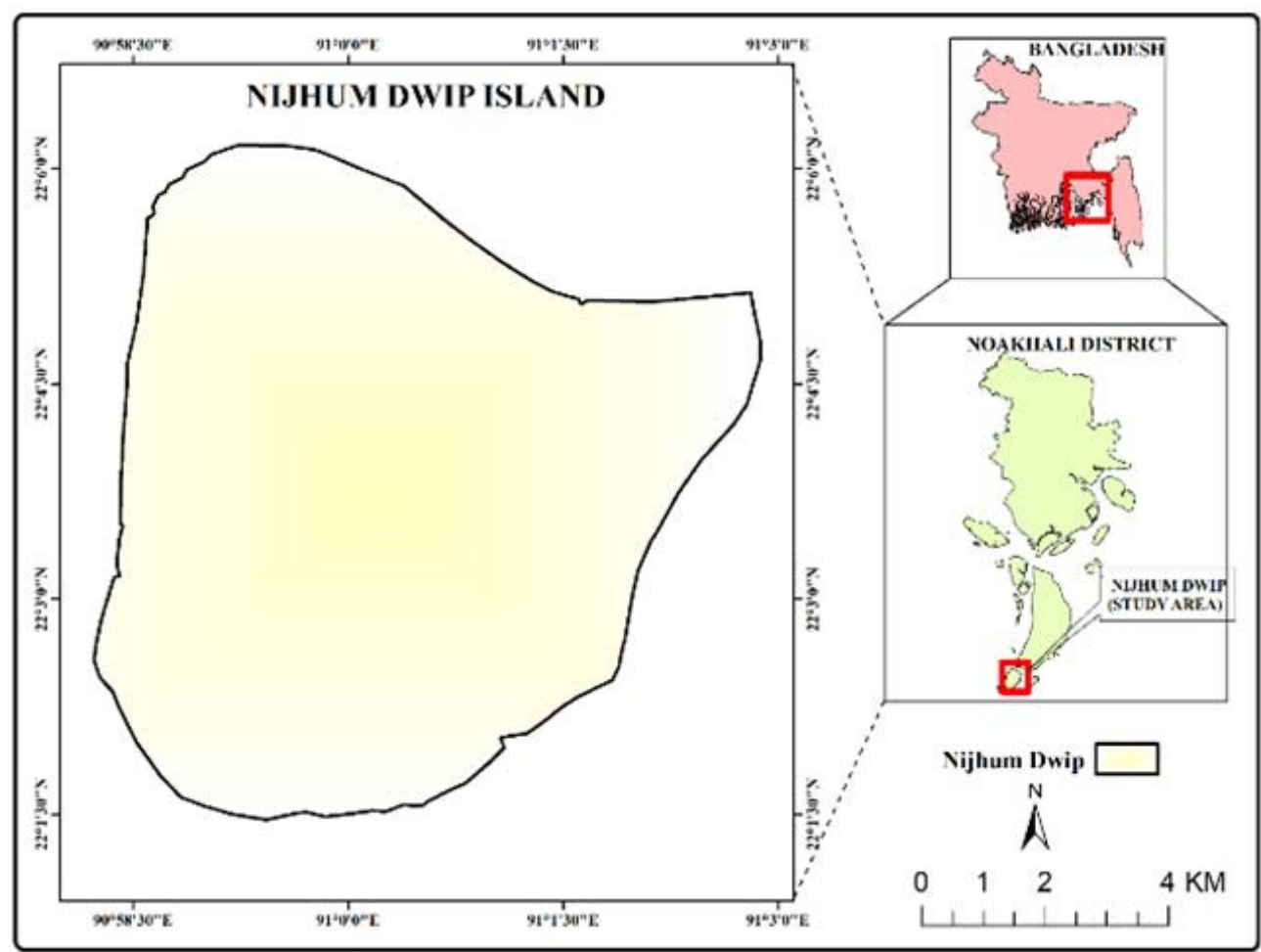

Figure 1: Location of Nijhum Dwip (Silent Island)

\section{Materials and Methods}

This study uses multi-temporal Landsat satellite images and data to analyze the spatial dynamics of Nijhum Dwip from 1980 to 2018 (Table 1). Five different Landsat images required to compare the land cover changes with spatial variation at the study area for 1980, 1990, 1999, 2010, and 2018. The satellite images of Landsat are Multispectral Scanner System (MSS) for 1980, Thematic Mapper (TM) for 1990, 1999, 2010, and Operational Land Imager (OLI) and Thermal Infrared Sensor (TIRS) for 2018 respectively. Images acquired from the United States Geological Survey (USGS) site (http://earthexplorer.usgs.gov/) based on data availability and cloud cover, only dry season and cloud- free Landsat scenes considered. Geometric correction conducted to rectify the image through UTM (Universal Transverse Mercator) projection system. 
Table 1: Properties of Used Satellite Images

\begin{tabular}{|c|c|c|c|c|c|}
\hline Satellite & Sensor & Band Number & $\begin{array}{l}\text { Path } \\
\text { Row }\end{array}$ & $\begin{array}{c}\text { Date of } \\
\text { Acquisition }\end{array}$ & $\begin{array}{c}\text { Spatial } \\
\text { Resolution }\end{array}$ \\
\hline Landsat & MSS & $4,5,6,7$ & $147 / 45$ & $\begin{array}{c}\text { November } \\
16,1980\end{array}$ & $60 \mathrm{~m}$ \\
\hline Landsat & $\mathrm{TM}$ & $1,2,3,4,5,6,7$ & $136 / 45$ & $\begin{array}{c}\text { October } 31 \\
1990\end{array}$ & $30 \mathrm{~m}$ \\
\hline Landsat & TM & $1,2,3,4,5,6,7$ & $137 / 45$ & $\begin{array}{c}\text { January } 16 \\
1999\end{array}$ & $30 \mathrm{~m}$ \\
\hline Landsat & $\mathrm{TM}$ & $1,2,3,4,5,6,7$ & $136 / 45$ & $\begin{array}{c}\text { November } \\
23,2010\end{array}$ & $30 \mathrm{~m}$ \\
\hline Landsat & $\begin{array}{l}\text { OLI \& } \\
\text { TIRS }\end{array}$ & $\begin{array}{l}1,2,3,4,5,6, \\
7,8,9,10,11\end{array}$ & $136 / 45$ & $\begin{array}{c}\text { December } \\
31,2018\end{array}$ & $30 \mathrm{~m}$ \\
\hline
\end{tabular}

Source: USGS Earth Explore (Accessed in 2019)

Analysis of coastline changes generally carried out using survey maps (Kadib 1969), past coastline mapping, and comparison of beach profiles over a long period (Inman and Jenkins 1985). Shoreline alteration monitoring needs a long-term observation based on the temporal variation modeling using remote sensing (RS) and geographic information system (GIS) (Bouchahma and Yan 2012). Identification, mapping, and analyses have gained importance in recent years as highresolution satellite data have become more accessible (Adegoke et al. 2010). Firstly, collected images clipped by using the area of interest (AOI). After that, manual digitization and classification have used to delineate the coastline and identify the land cover from each image rather than automated technique at the same scale under similar zooming level by using ArcGIS 10.5 software and its extensions. Land cover change detection assessed by the processing of multi-temporal images (1980-2018), differencing, overlaying the postclassification images, visual interpretation, and onscreen digitizing (Ahmadi et. al 2014). Six categories of land use and land cover identified naming water bodies, char land, open space, agricultural land, settlement, and vegetation through supervised classification. On the other side, two temporally succeeding coastline boundaries for the island compared to calculate shoreline shifting, increase or decrease using GIS overlay techniques. Then topological error has corrected through the conversion tool. In addition, annual shifting for each epoch calculated from the total movement and the number of years in that epoch. Meanwhile, the entire summary of extracted data shown and interpreted through tables and represented by maps and Diagrams.

\section{Result and Discussion}

a) Changes on Land Surface: Land cover and land use (LCLU) analysis are fundamental to assess the changes of past and current land association due to natural processes and local land utilizations by the people. For this reason, the land use pattern of this island became examined from 1980 to 2018 (Figure 2 ), and evident from the interpretation of satellite images that Nijhum dwip undergoes a continuous change. In 1980, vegetation cover was 8.02 km2, which was $27.71 \%$ of the total land cover, whereas, during 1990 , the vegetated area increased by 18.70 $\mathrm{km} 2$ that was $55.61 \%$ of the entire land use and land cover. Later, in 1999, 2010, and 2018 green area decreased gradually from $20.97 \mathrm{~km} 2$ to $18.47 \mathrm{~km} 2$ and $15.28 \mathrm{~km} 2$ which was $52.29 \%, 36.28 \%$, and $31.98 \%$ respectively. Results indicate that in 1980 vegetated area was less than 1990 because that time land was newly formed, barren, and took time to grow vegetation. In 1990, vegetation grew on the mature developed fertile landform, and after that, vegetation cover decreased because of the more accessibility of surrounding peoples. In the study area, forest converted to other lands by human intervention such as clearing and converting of forestland to cropland and settlements, when forest converted to water by natural processes such as coastal erosion. Besides, other lands to forest and water to forest altered when newly accreted land (formed in the sea) later planted with the mangroves (Rahman et. al. 2018). On the contrary, a reverse situation such as increasing with slight drop observe 
in the case for agricultural land because more people started to involve with cropping as economic activities. In 1980, there were no suitable lands which utilized for agricultural practice but subsequently, $4.47 \mathrm{~km} 2 \quad(13.29 \%), 4.84 \mathrm{~km} 2$
(12.07\%), $6.44 \mathrm{~km} 2$ (12.76\%), $9.16 \mathrm{~km} 2(19.17 \%)$ land used for cropping in 1990, 1999, 2010 and 2018 respectively (Figure 2 and 3), where agricultural land was increasing continuously after 1990.

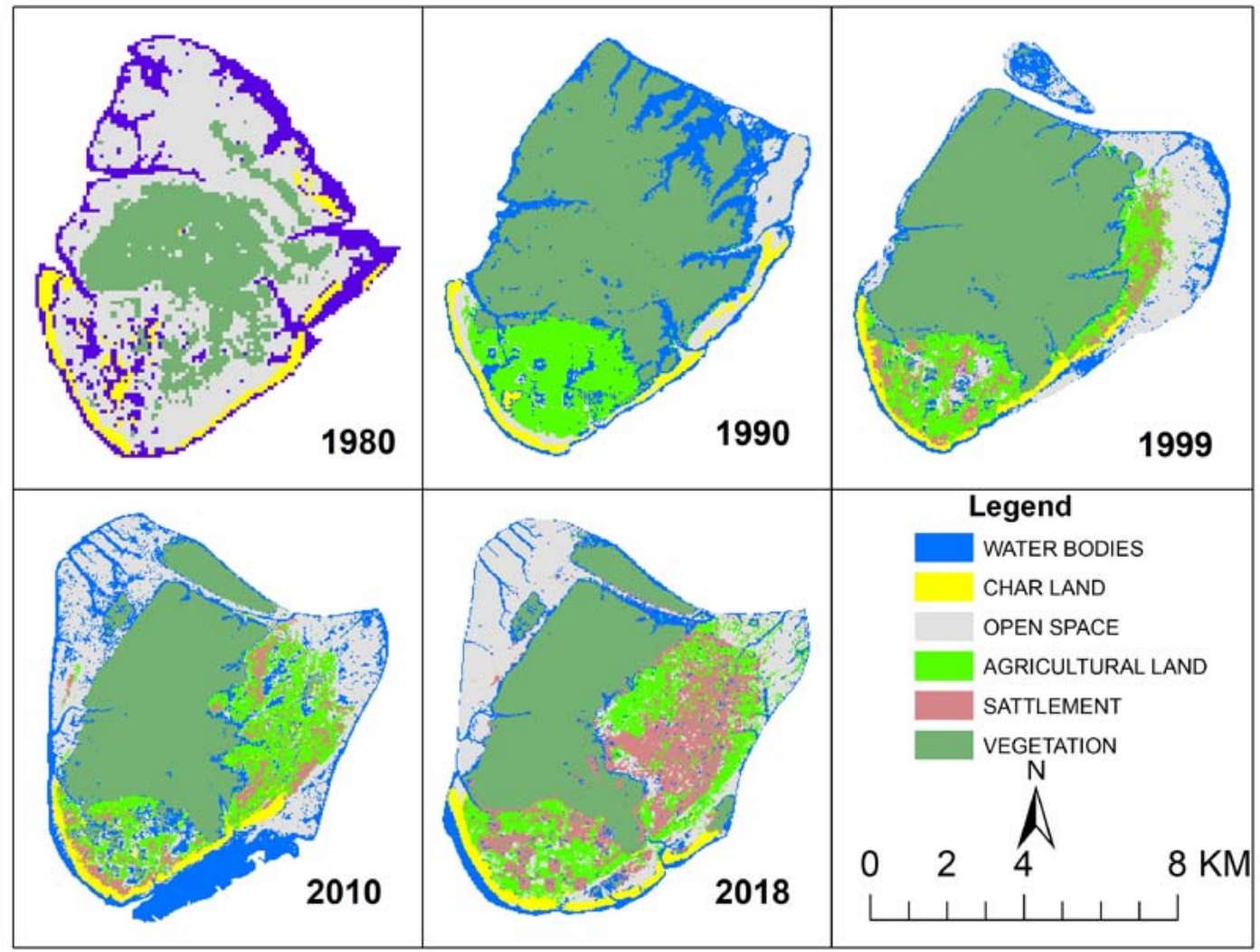

Figure 2: Land use and land cover classification

However, inland water bodies in the study area are a fluctuating phenomenon because of their location in the estuary which is always active, unpredictable, and due to erosion-accretion amount variation. Maximum inland water bodies were $9.76 \mathrm{~km} 2$ (19.36\%) in 2010 and $4.68 \mathrm{~km} 2(9.79 \%)$ was minimum in 2018. Along with, $5.45 \mathrm{~km} 2$ (18.83\%), $6.42 \mathrm{~km} 2$ (19.09\%), $4.40 \mathrm{~km} 2$ (10.97\%) area were as water body in 1980, 1990 and 1999 respectively. Likewise, char lands were another changeable feature because of varied fluvial and marine geomorphological agents and processes. Accordingly, $1.68 \mathrm{~km} 2$ (5.80\%), $1.15 \mathrm{~km} 2$ (3.42\%), $1.24 \mathrm{~km} 2$ (3.09\%), $1.57 \mathrm{~km} 2(3.11 \%)$ and $1.61 \mathrm{~km} 2(3.37 \%)$ was as char lands along the riverside in 1980, 1990, 1999, 2010 and 2018. On the other hand, $13.78 \mathrm{~km} 2(47.62 \%), 2.87 \mathrm{~km} 2$ (3.06\%), $6.72 \mathrm{~km} 2$ (16.76\%), $11.61 \mathrm{~km} 2$ (23.03\%), 11.31 $\mathrm{km} 2(23.67 \%)$ identified as open space on the land surface in 1980, 1990, 1999, 2010 and 2018 consequently. However, in the analysis open space is showing a frequent change than the other land-use types. Furthermore, with time this landmass turned into a lucrative place for seasonal migrants and then permanent settlement. Developed char lands or islands like Burir char, Sukh char, Sonadia, etc. might be another choice but people are moving to the Nijhum Dwip rather than shifting to the mainland despite facing numerous disasters like cyclones, riverbank erosion, flood, storm surge, sea-level rise, salinity intrusion, etc. considering livelihood opportunities, low price of land and have no other options (Kumar and Luna, 2018). Although, primarily the island was just an afresh settled sediment deposited landmass in the Meghna estuary without human population. Thus, there was no settlement in the years 1980 and 1990 since the land was less suitable for settlement and agriculture than older land. Afterward, $1.92 \mathrm{~km} 2,2.56 \mathrm{~km} 2$, and 5.72 $\mathrm{km} 2$ area occupied and which were $4.79 \%, 5.09 \%$, and $11.97 \%$ out of the total land surface in 1999, 2010, and 2018 for settlement on the mainland (Figure 2 and 3). The abovementioned findings of the study area indicating that more population settlement, expansion of infrastructure each year on the island, and more land utilization for agricultural practice, farming, etc. are the main reasons for open space and vegetation cover reduction. 


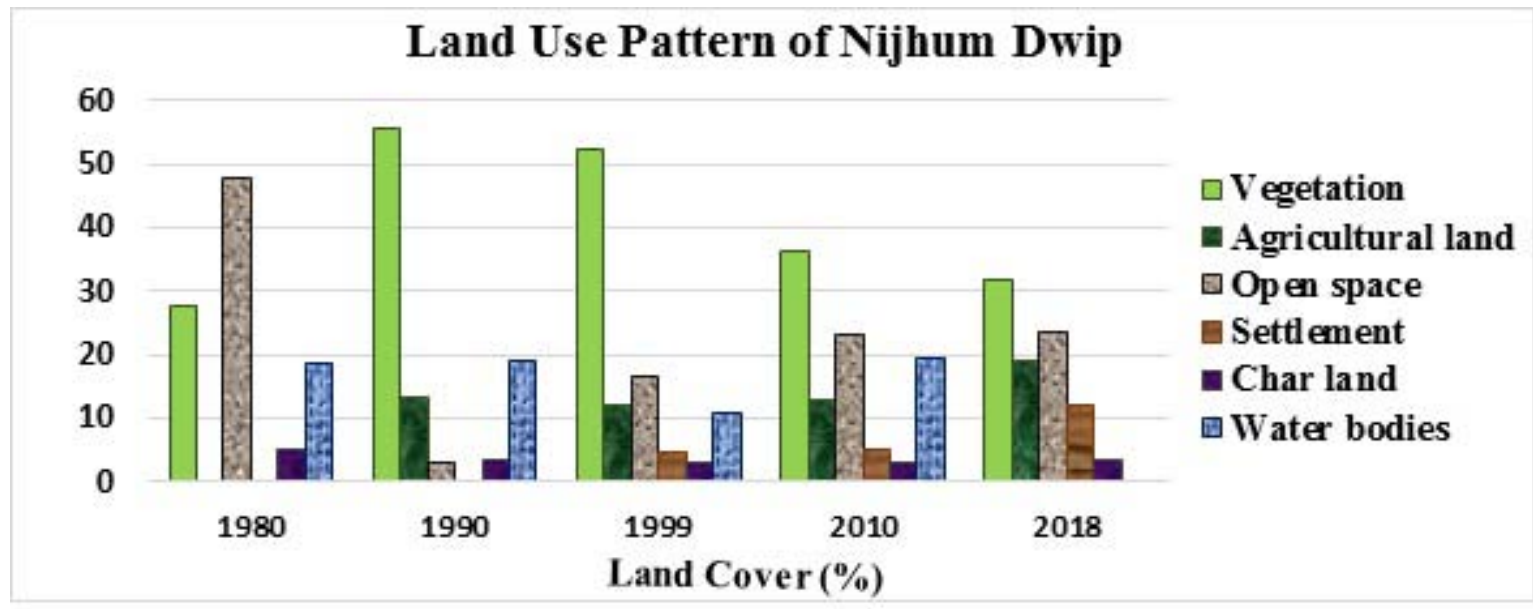

Figure 3: Percentage of Land use and Land cover Area

b) Coastline Shifting: The study area is an energetic zone on the shores of the Bay of Bengal as an oversized volume of sediment from the GangesBrahmaputra-Meghna (GBM) river systems deposited here (Hossain et al., 2016) and for this reason, coastline continuously changes under different physical and social condition. Nijhum Dwip is principally an unstable landform traversed by inter-tidal narrow creeks. The whole area of Nijhum Dwip was $28.94 \mathrm{~km} 2$ in 1980 and after a decade in 1990, the area increased by $33.63 \mathrm{~km} 2$. Later, the area enlarged by $40.10 \mathrm{~km} 2$ and $50.41 \mathrm{~km} 2$ in 1999 and 2010 by reason of sediment accretion. From
1980 to 2010, Nijhum Dwip total surface area shows enlargement by accretion of sediments coming with river water and regular tides, waves from ocean, river. within the period of 1980 to 1990, the rate of enlargement is $0.469 \mathrm{~km} 2$ annually. Similarly, 0.719 $\mathrm{km} 2$ and $0.937 \mathrm{~km} 2$ land increased per annum over the period of 1990-1999 and 1999-2010. Then again, in 2018 total area of the island decreased than the previous by $47.78 \mathrm{~km} 2$, when erosion was more than deposition. Although $0.328 \mathrm{~km} 2$ area reduced by erosion annually for the period of 2010 to 2018 (Figure 4).

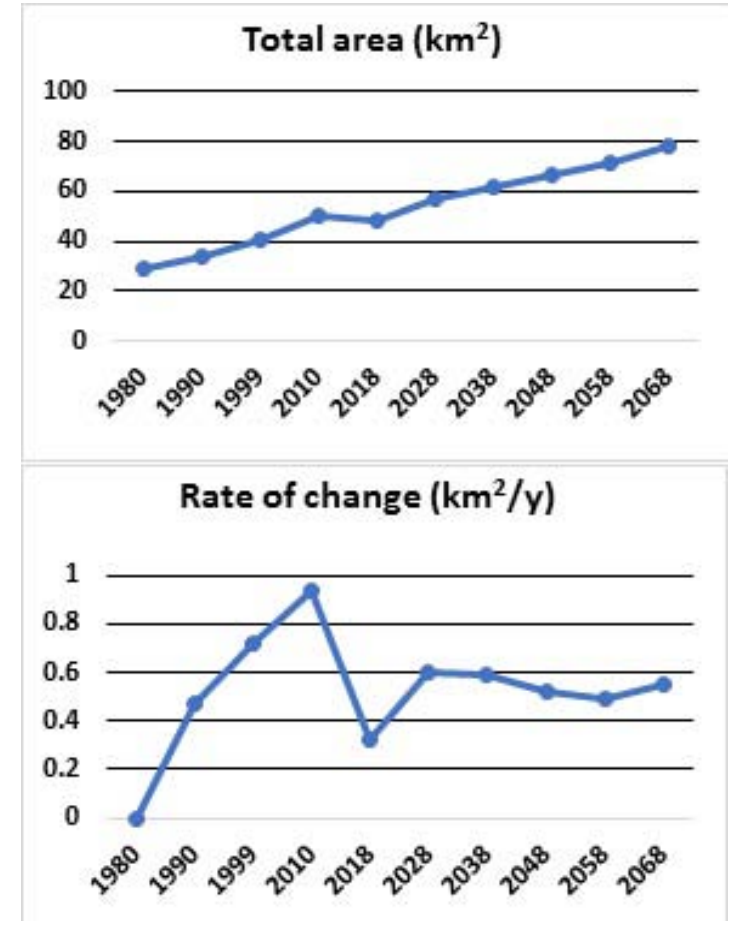

Figure 4: Total Area and Rate of Change with projection (1980-2068)

Comparison of Landsat images in 1980,1990, 1999, 2010, and 2018 shows a net land gain of 18.84 km2 in the Meghna estuary within that period (1980-
2018), representing an average annual growth rate of $0.496 \mathrm{~km} 2$, and again lost about $2.63 \mathrm{~km} 2$. This analysis of land variation in the Meghna estuary demonstrates 
that land gain might exceed land loss resulting from the slow rate of erosion (Figures 4 and 5). After that, a projection from 2028 to 2068 produced based on existing total area and rate of change per year data to evaluate the pattern of transformation and increase of land surface forecasted here because the overall accretion rate is over than the rate of erosion in Nijhum Dwip (Figure 4). However, the direction of the accretion and erosion on the island varies from year to year and it is a lively process. From 1980 to 1990, the coastline changed by raising and decreasing towards the northeast through deposition and erosion. Later, from 1990 to 1999, the shoreline extended westwards whereas from 1999 to 2010 shoreline shifted to the northwest by sediment deposits. Then again within the period of 2010 to 2018, the overall reduction of the landmass observed on the southwest and southeast edge. Hence, it is visible that the upper north part of Nijhum Dwip is shifting by enlargement of landmass towards the north, north-east and north-west direction than the southern part which is mostly sediment wearing away prone side of the island (Figure 5).

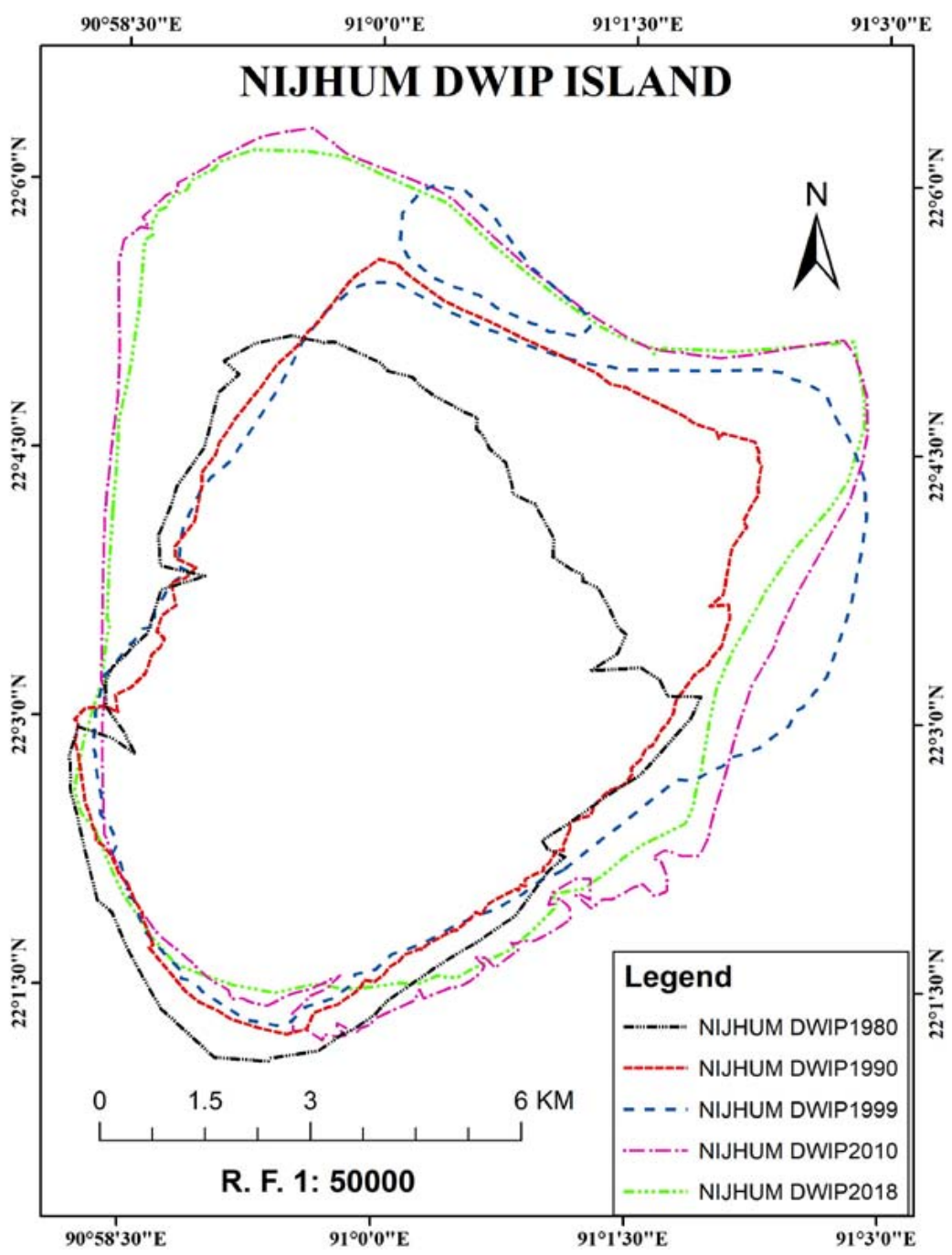

Figure 5: Coastline Shifting (1980-2068) of Nijhum Dwip

\section{Conclusion}

Conversions of land like, from non-buildup barren open space or char land to settlement and farming; naturally vegetated area cleared for agricultural practice, etc. have resulted within the study area. The entire area of an intertidal zone has increased over time, though the findings and analysis show increases in agriculture, becoming more intermixed with settlements.
It is apparent that land utilization is usually direct by the population growth, development activities putting pressure, and filling of low-lying areas, and clearing of vegetation may result from erosion of topsoil and a large range of negative environmental impacts. However, expansion and reduction of landform largely rely on land gaining and losing with the influence of coastal geomorphological agents and processes. Sustainable 
land-use planning and releasing overpressure is indispensable for this type of coastal island like Nijhum Dwip in Bangladesh, and deliberation, therefore, must obtain addressing proper development.

\section{References Références Referencias}

1. Adegoke, J. O., M. Fageja, G. James, G. Agbaje and T. E. Ologunorisa. 2010. An Assessment of Recent Changes in the Niger Delta Coastline Using Satellite Imagery. Journal of Sustainable Development, 3(4), 277-296. DOI:10.5539/jsd.v3n4 p277

2. Ahmadi, M., M. Ramesht and K.Derafshi. 2014. Detection of shoreline changes using remote sensing and GIS techniques, case study: Coast port city Dayer, Persian Gulf. Geography and Environmental Planning Journal, 55(3), 15-18.

3. Alam, M. S., \& Uddin, K. (2013). A Study of Morphological Changes in the Coastal Areas and Offshore Islands of Bangladesh Using Remote Sensing. American Journal of Geographic Information System, 2(1), 15-18. DOI: 10.5923/j. ajgis.20130201.03

4. Anderson, J.R., Hardy, E.E., Roach, J.T., \& Witmer, R.E. 1976. A land use and land cover classification system for use with remote sensor data. U.S. Geological Survey Professional Paper, No. 964. USGS, Washington, D.C.

5. BBS. (2011). Bangladesh Population Census of Hatiya Upazila. Bangladesh Bureau of Statistics, Ministry of Planning, Government of the People`s Republic of Bangladesh, Dhaka.

6. BBS. (2011). Population and Housing Census 2011. Bangladesh Bureau of Statistics, Ministry of Planning, Government of the People`s Republic of Bangladesh, Dhaka.

7. Bouchahma, M. and W. Yan, 2012. Automatic measurement of shoreline changes on Djerba Island of Tunisia. Computer and Information Science, 5(5), 17-24. DOI:10.5539/cis.v5n5p17

8. Brammer, H., (2014). Bangladesh's dynamic coastal regions and sea-level rise. Climate Risk management, 1(2014), 51-62. http://dx.doi.org/10. 1016/j.crm.2013.10.001

9. Di Gregorio, A., \& Jansen, L.J.M. (1997). A new concept for a land cover classification system. Proceedings of the Earth Observation and Environmental Information 1997 Conference, Egypt, 13-16 October 1997.

10. Earth Explorer. (2019). USGS.gov, Science for a changing world. U.S. Geological Survey (USGS). https://earthexplorer.usgs.gov/

11. Emran, A., Rob, M. A., \& Kabir, M. H. (2016). Coastline Change and Erosion-Accretion Evolution of the Sandwip Island, Bangladesh. International
Journal of Applied Geospatial Research, 8(2), 33-44. DOI:10.4018/IJAGR.2017040103

12. Hassan, S.M.T, Syed, M.A, \& Mamnun, N. (2017). Estimating Erosion and Accretion in The Coast of Ganges-Brahmaputra-Meghna Delta in Bangladesh. 6th International Conference on Water \& Flood Management (ICWFM-2017), 115-124. https://www. researchgate.net/publication/315647843

13. Hossain, K.T., Tanim, I.A. \& Saluddin, M. (2016). Change Detection of Forest Cover: A study Nijhum Dwip Natioal, Park,Hatiya, Noakhali. Jagannath University Journal of Life and Earth Sciences, 2 (1 \& 2), 54-90. https://www.researchgate.net/publica tion/323255434

14. Hossain, K.T., Saluddin, M. \& Tanim, I.A. (2016). Assessment of the dynamics of coastal island in Bangladesh using geospatial techniques: domar char. J. Asiat. Soc. Bangladesh Sci, 42(2), 219-228. http://www.asiaticsociety.org.bd/journal/9.\%20S\%20 1623\%20Corrected\%205.3.pdf

15. Hossain, M.S., Rahman, M. F., Thompson, S., Nabi, M.R. and Kibria, M. M. (2013). Climate change resilience assessment using livelihood assets of coastal fishing community in Nijhum Dwip, Bangladesh. Pertanika Journal of Science \& Tecnology, 21(2), 397-422. https://www.research gate.net/publication/234894032

16. Iftekhar, M.S. (2006). Conservation and management of the Bangladesh coastal ecosystem: Overview of an integrated approach. Natural Resources Forum, 30(3), 230-237. DOI:10.1111/j. 1477-8947.2006.00111.x

17. Inman, D. L., and S. A. Jenkins. 1985. The Nile littoral cell and man's impact on the coastal zone of the southeastern Mediterranean. In Coastal Engineering. 1984: 1600-1617.

18. Islam, M. A., Hossain, M. S. \& Murshed, S. (2015). Assessment of Coastal Vulnerability Due to Sea Level Change at Bhola Island, Bangladesh: Using Geospatial Techniques. Journal of Indian Society of Remote Sensing, 43(3), 625-637. DOI: 10.1007/s 12524-014-0426-0

19. Kadib, A. 1969. Sand movement along a portion of the northern coast of United Arab Republic. 22nd International Navigation Congress: 273-287.

20. Kumar, A \& Luna. S.S. (2018). Migrant community of nijhum dwip: comparative importance of livelihood capitals to adapt in this island. J. Asiat. Soc. Bangladesh, Sci., 44(2), 127-136. https://www.asia ticsociety.org.bd/journal/S_Dec_2018/3_S_Dec_201 8.pdf

21. Kumara, L. \& Ghosh, M. K. (2012). Land cover change detection of Hatiya Island, Bangladesh, using remote sensing techniques. Journal of Applied Remote Sensing, 6(1). DOI:10.1117/1.JRS.6.063608 
22. Lillesand, T.M. \& Kiefer, R.W. (2002). Remote Sensing and Image Interpretation. John Wiley and Sons, Inc. New York.

23. Lu, D., Mausel, P., Brondi'zio, E. \& Moran, E. (2004). Change detection techniques. International Journal of Remote Sensing, 25(12), 2365-2407. DOI:10.1080/0143116031000139863

24. Rahman, M. M., Pramanik, M. A. T., Islam, M. I. \& Razia, S. (2018). Mapping Mangrove Forest Change in Nijhum Dwip Island. J. Environ. Sci. \& Natural Resources, 11(1\&2), 217-225. DOI: 10.3329/jesnr. v11i1-2.43388

25. Rahman, M.K., Schmidlin, T. W., Munro-Stasiuk, M. J., \& Curtis, A. (2017). Geospatial Analysis of Land Loss, Land Cover Change, and Landuse Patterns of Kutubdia Island, Bangladesh. International Journal of Applied Geospatial Research, 8(2). DOI:10.4018/ IJAGR.2017040104

26. Rahman, M., Tanjim, M.F., Dey, S.C., Azam, A.K.M.S. and Islam, M.R. (2012). Alternative livelihood options of fisherman of Nijhum Dwip under Hatiya Upazila of Noakhali District in Bangladesh. Asian Journal of Rural Development, 2(2), 24-31. DOI:10.3923/ajrd.2012.24.31

27. Saha, P.K., Bodiuzzaman, M., Uddin, M.N., Hossain, M.N. \& Shanta, A.S. (2014). A Study on the Management Strategies of Protected Area in Bangladesh for Biodiversity Conservation on Nijhum Dwip, Noakhali, Bangladesh. International Journal of Innovative Research \& Development, 3(7), 140-148. http://citeseerx.ist.psu.edu/viewdoc/download?doi= 10.1.1.911.957\&rep=rep1\&type $=$ pdf

28. Sarwar, M. G. M. (2005). Impacts of Sea Level Rise on the Coastal Zone of Bangladesh. Lund University International Master's Programme in Environmental Science, Lund University, Sweden. https://www. lumes.lu.se/sites/lumes.lu.se/files/golam_sarwar.pdf

29. Sarwar, M. G. M. \& Woodroffe, C. D. (2013). Rates of shoreline change along the coast of Bangladesh. Journal of Coastal Conservation, 17(3), 515-526. http://ro.uow.edu.au/smhpapers/1105

30. Schwartz, M. (Ed.). (2006). Encyclopedia of coastal science. Encyclopedia of Earth Sciences Series. Springer Netherlands. 978-1-4020-3880-8

31. Shibly, A. M. \& Takewaka, S. (2012). Morphological Changes along Bangladesh Coast Derived from Satellite Images. Proceedings of Coastal Engineering. JSCE. 3, 41-45. https://coastal.jp/cecint/CEC-Int-2012/CEC-Int-2012-09.pdf

32. Singh, A. (1989). Digital change detection techniques using remotely sensed data. Int. J. Remote Sensing, 10, 989-1003. http://dx.doi.org/10. 1080/01431168908903939

33. Tanim, S.H. \& Roy, D.C. (2013). Climate Induced Vulnerability and Migration of the People from Islands of Bangladesh: A Case Study on Coastal Erosion of Kutubdia Island. Planned
Decentralization: Aspired Development. World Town Planning Day.

34. PDO-ICZMP (Program Development Office for Integrated Coastal Zone Management Plan). (2002). Inventory of Coastal and Estuarine Islands \& Chars. 06, Dhaka. http://warpo.portal.gov.bd/sites/default/ files/files/warpo.portal.gov.bd/page/aa04373f_0ca3 49a5_b77e_5108186638dc/Inventory.PDF

35. Üddin, A. M. K., \& Kaudstaal, R. (2003). Delineation of the coastal zone Dhaka. Program Development Office for Integrated Coastal Zone Management Plan (PDO-ICZMP). WP005, Bangladesh. http://warpo. portal.gov.bd/sites/default/files/files/warpo.portal.go v.bd/page/aa04373f_0ca3_49a5_b77e_5108186638 dc/wp005.PDF. 